A23L 1/06. № u201003479; declared. 25.03.2010; published. 27.09.2010, № 18 .

6. Bogomolova, V. V. (2010). Preparation of canned fish in jelly. Patent of Ukraine for useful model. A23L 1/325, A23B 4/00. № a 200900303; declared. 16.01.2009; published. 25.10.2010, (20).

7. Kuznetsova, L. S. (2006). Perspektivyi ispolzovaniya karraginanov $\mathrm{v}$ konditerskom proizvodstve (dlya proizvodstva zheleynyih konfet $\mathrm{s}$ funktsionalnyimi svoystvami) [Prospects for the use of carrageenan in the confectionery industry (for the production of jelly candies with functional properties]. Confectionery and Bakery, 6, 6-8.

8. Rees, D. A. (1981). Polysaccharide shapes and their interactions - some recent advances. Pure and Applied Chemistry, 53 (1), 1-14. doi: 10.1351/pac198153010001

9. Smidsrod, O., Andresen, I., Grasdalen, H., Larsen,

B., Painter, T. (1980). Evidence for a salt-promoted "freeze- out" of linkage conformations in carrageenans as a prerequisite for gel-formation. Carbohydrate Research, 80 (1), C11-C16. doi: 10.1016/s0008-6215(00)85333-1

10. Nechaev, A. P., Kochetkova, A. A., Zaytsev, A. I. (2002). Pischevyie dobavki [Nutritional Supplements]. Moscow: Kolos, Kolos-Press, 256.

11. Vodorosli morskie, travyi morskie i produktyi ih pererabotki. Metodyi analiza: GOST 26185 [Seaweeds, sea grasses and products of their processing. Methods of analysis: GOST 26185] (2010). [Introduced 01.01.85]. Moscow: STANDARTINFORM, 36.

12. Zdobnov, A. I., Tsyiganenko, V. A. (2009). Sbornik retseptur blyud i kulinarnyih izdeliy: dlya predpriyatiy obschestvennogo pitaniya [Collection of recipes of food and culinary products: for catering]. Kiev, Ukraine: Publisher Arius, Moscow, Russia: Lada, 680.

Дата надходження рукопису 18.06.2015

Гурський Петро Васильович, кандидат технічних наук, доцент, професор, кафедра обладнання та інжинірингу переробних і харчових виробництв, Харківський національний технічний університет сільського господарства ім. П.Василенка, вул. Артема, 44, м. Харків, Україна, 61002

E-mail: gurskiy_peter@mail.ru

Маренкова Тетяна Іванівна, старший викладач, здобувач, кафедра технології харчування, Сумський національний аграрний університет, вул. Кірова, 160, м. Суми, Україна, 40021

E-mail: tanya201@ukr.net

Бідюк Дмитро Олегович, кандидат технічних наук, старший викладач, кафедра технологій переробних і харчових виробництв, Харківський національний технічний університет сільськогогосподарства ім. П.Василенка, вул. Артема, 44, м. Харків, Україна, 61002

E-mail: xbach@mail.ru

Перцевой Федір Всеволодович, доктор технічних наук, професор, кафедра технології харчування, Сумський національний аграрний університет, вул. Кірова, 160, м. Суми, Україна, 40021

УДК 614.842.628

DOI: $10.15587 / 2313-8416.2015 .46150$

\title{
QUALITY METRICS FOR ELABORATED AQUEOUS FIRE EXTINGUISHING SUBSTANCE ON BASE OF COPPER(II) CHLORIDE
}

\author{
(C) B. Mykhalichko, O. Scherbina, O. Mykhalichko, V. Petrovskii
}

Research results relating to the measurement of kinematic viscosity, surface tension, density, acidity and other quality metrics (consistence, freezing point, etc.) for recently elaborated aqueous fire extinguishing substance (AFES) made up of $40 \%$ aqueous solution of copper(II) chloride with added different amounts of surface-active substance are presented in this article

Keywords: inhibitors of burning, copper(II) salts, aqueous fire extinguishing substance, fire-extinguishing aerosol, quality indices

В роботі наведені результати досліджень з вимірювання кінематичної в'язкості, поверхневого натягу, густини, кислотності та деяких інших показників якості (консистенція, температура замерзання тощуо), для нещзодавно розробленої водної вогнегасної речовини (ВВР) на основі 40 \% водного розчину купрум(II) хлориду за умов додавання різної кількості поверхнево-активної речовини

Ключові слова: інгібітори горіння, солі купрум(II), водна вогнегасна речовина, аерозольне вогнегасіння, показники якості

\section{Introduction}

Aqueous fire extinguishing substances (AFESs), being intended primarily for use in fire suppression systems, mostly consist either of water (distilled, deionized, drinking, technical, marine etc.) or aqueous solutions of salts-inhibitors of burning or of water with additives modifiers that provide the required quality metrics for AFES.
Systematic study of behavior of various water solutions of inorganic salts in a flame have allowed in the beginning of the third millennium to discover the exceptional capability of the concentrated aqueous solution of copper(II) chloride $[1,2]$ to the flame suppressing. But, even after such epoch-making discovery, the broad application of these solutions in technology of fire suppressing by aerosols [3] is largely restricted by the lack 
of regulatory regime, including requirements regarding of quality metrics for the elaborated AFES.

\section{Statement of the problem}

Currently, technology of spraying AFESs for the flame suppressing is widely used in firefighting practice $[4,5]$. However, salts dissolved in water to the full provide the realization of unique physical and chemical properties of water and such solutions appreciably heighten the fire extinguishing effect $[6,7]$. Furthermore, by adding even of the surface-active substances traces, quality metrics of aqueous solutions of salts-inhibitors can be significantly improved [8].

\section{Literature review}

Among the well-dissoluble chemicals in water the salts of alkali metals and ammonium in many works [9, 10] are traditionally considered as perfect inhibitors of burning. However, the elaborations concerning creation of new AFESs on the basis of salts of transition metals have too appeared in the world practice of firefighting lately. Efficiency of fire extinguishing by means of aerosols of aqueous solutions of such salts is conditioned by special chemical properties of $d$-metals (electron acceptors) capable to the exceptional suppressing of flame [11]. Within this type of inhibitors of burning, copper(II) salts [1] deserve special attention. In particular, the $40 \%$ aqueous solution of copper(II) chloride is very efficient agent that effectively can inhibit the hydrocarbon flame [2]. The foaming agent (FA) of special purpose "Snizok-1" has also been used by us as additive of surface-active substance for providing the more effective suppressing of flame. That is why the study of quality metrics for solutions of this type has been the object of our research.

Therefore, by the aim of work have been ascertainment of such fundamental indices of quality as solution appearance, kinematic viscosity, surface tension, freezing-point, acidity and density of $40 \%$ aqueous solution of copper(II) chloride with added certain amounts of surface-active substance "Snizok-1". Besides, the possibility of wide application of this elaboration in firefighting with using technology of spraying AFESs also has been discussed.

\section{Materials and methods}

The chemicals: $\mathrm{CuCl}_{2} \cdot 2 \mathrm{H}_{2} \mathrm{O}$ (the basis of AFES) and the ammonium $n$-alkylsulfate with general formula of $\mathrm{C}_{n} \mathrm{H}_{2 n+1} \mathrm{SO}_{4} \mathrm{NH}_{4}^{+}$, where $n=12-16$ (the basis of FA "Snizok-1") were obtained from commercial sources and used as-received without further purification.

The quality metrics of prepared AFES have been characterized by means of modern methods of physical and chemical analysis. The kinematic viscosity has been measured by viscosimetric method (viscosimeter VLA-1 with an inner diameter of capillary having $0.99 \mathrm{~mm}$ ). The surface tension has been determined by method count of drops using stalagmometer. The determination of the specific density of AFESs has been performed by bottle method and acidity of $40 \%$ aqueous solution of $\mathrm{CuCl}_{2}$ was realized by using $\mathrm{pH}$-meter. The freezing point of the solution has been esti-mated by means of the second Raul's law. The characteristics of instrumentations that were used for determination of the quality metrics of AFESs are given in Table 1.

Table 1

Instrumentation characteristics used for the experimentations

\begin{tabular}{|c|c|c|c|}
\hline No & Instrumentation (type) & Measurement range & Measuring fault \\
\hline 1 & Stopwatch (HS-43) & from 0 to $3600 \mathrm{~s}$ & $0.4 \Delta \tau_{\text {measur }} / 60 \mathrm{~s}$ \\
\hline 2 & Mercurial thermometer (TM-1) & from -30 to $+70{ }^{\circ} \mathrm{C}$ & $0.5{ }^{\circ} \mathrm{C}$ \\
\hline 3 & Viscosimeter (VLA-1) & from 0.6 to $1000 \mathrm{~mm}^{2} \cdot \mathrm{s}^{-1}$ & $0.35 \%$ \\
\hline 4 & Stalagmometer (ST-1) & from 20 to $80 \mathrm{mN} \cdot \mathrm{m}^{-1}$ & $0.1 \%$ \\
\hline 5 & Electronic balance (EWT-200) & from 0 to $200 \mathrm{~g}$ & $0.001 \mathrm{~g}$ \\
\hline 6 & pH-meter (150MI) & from 0 to 14 & $0.004 \mathrm{pH}$ units \\
\hline 7 & Aneroid barometer (M67) & from 600 to $800 \mathrm{~mm} \mathrm{Hg}$ & $0.5 \mathrm{~mm} \mathrm{Hg}$ \\
\hline 8 & Liquid thermostat (U-10) & from 20 to $100{ }^{\circ} \mathrm{C}$ & $0.1^{\circ} \mathrm{C}$ \\
\hline 9 & Picnometers & 10,25 and $50 \mathrm{~cm}^{3}$ & $0.001 \mathrm{~cm}^{3}$ \\
\hline 10 & Graduated cylinder & from 50 to $500 \mathrm{~cm}^{3}$ & $1 \mathrm{~cm}^{3}$ \\
\hline
\end{tabular}

\section{Results and discussion}

\section{1. Consistence, acidity and freezing point of} $\mathrm{CuCl}_{2}$-containing AFES

The solution state of $40 \%$ aqueous solution of $\mathrm{CuCl}_{2}$ (AFES) has been estimated visually. We have kept an eye on the presence or absence of delamination as well as sediment formation during of visual examination of the samples in scattered light after two-hour staying at $20{ }^{\circ} \mathrm{C}$ in $50 \mathrm{~mL}$ cylinder. In appearance the obtained aqueous solutions of copper(II) chloride of different concentrations without and with foaming agent added to the $50 \mathrm{~mL}$ of AFES in volume $0.05-1.00 \mathrm{~mL}$ seem homogeneous molecular-disperse phase having deep emerald color.
The acidity was determined for distilled water, pure foaming agent "Snizok-1" and $40 \%$ aqueous solution of $\mathrm{CuCl}_{2}$ at $20^{\circ} \mathrm{C}$. Values of acidity measured for listed above sequence amount 7.10, 8.6 and $1.07 \mathrm{pH}$ units.

For determination of such physical and chemical characteristics of $40 \%$ aqueous solution of $\mathrm{CuCl}_{2}$ as freezing temperature we have made use of the equation known as the second Raul's law according to which was calculated $\Delta T_{\text {freez }}$ of electrolyte solution of $\mathrm{CuCl}_{2}$, it can be written as

$$
\Delta T_{\text {freez }}=K_{\text {water }} \cdot C_{\mathrm{m}} \cdot i,
$$

where $\Delta T_{\text {freez }}$ is decrease of freezing temperature of solution comparatively with freezing temperature of water, 
$K_{\text {water }}$ is cryoscopic constant for water that has the value $1.86 \mathrm{~K} \cdot \mathrm{g} \cdot \mathrm{mole}^{-1}, i$ is isotonic coefficient which in case of aqueous solution of $\mathrm{CuCl}_{2}$ can take on the value $3, C_{\mathrm{m}}$ (mole $\cdot \mathrm{kg}^{-1}$ of $\mathrm{H}_{2} \mathrm{O}$ ) is molal concentration of $40 \%$ aqueous solution of $\mathrm{CuCl}_{2}$ that was calculated in terms of the weight/weight percent $(\omega, \%)$ by means of the relationship

$$
\mathrm{C}_{\mathrm{m}}=\frac{\omega \cdot \mathrm{m}_{\text {solution }} \cdot 10}{\mathrm{M}_{\text {solute }} \cdot \mathrm{m}_{\text {solvent }}} .
$$

Thus, calculated freezing temperature of $40 \%$ aqueous solution of copper(II) chloride assume of $33,7^{\circ} \mathrm{C}$ value.

\section{2. The kinematic viscosity for samples of} AFESs with FA

The kinematic viscosity, $\eta$, of testing samples has been determined by viscometric method whose gist consists in measurement of duration of flowing-out through capillary of the certain volume of sample out of reservoir of viscometer under influence of gravitational force. The value of $\eta$ is calculated using the equation in form

$$
\eta=\frac{g_{1}}{g_{0}} C \Delta \tau
$$

where $g_{1}=9.8057 \mathrm{~m} \cdot \mathrm{s}^{-2}$ is free fall acceleration in L'viv (latitude 45.82 North), $g_{0}=9.8066 \mathrm{~m} \cdot \mathrm{s}^{-2}$ is free fall acceleration on the Equator (latitude 0), $C=$ $=0.09109 \mathrm{~mm}^{2} \cdot \mathrm{s}^{-2}$ is viscometer constant and $\Delta \tau(\mathrm{s})$ is duration of flowing-out.

The measurement results of kinematic viscosity for samples composed of $40 \%$ aqueous solution of copper(II) chloride $(50 \mathrm{~mL})$ with added certain volumes of foaming agent are summarized in the Table 2; the graphical relationship between values of $\eta$ and volume $(V, \mathrm{~mL})$ of added FA "Snizok-1" is displayed in Fig. 1.

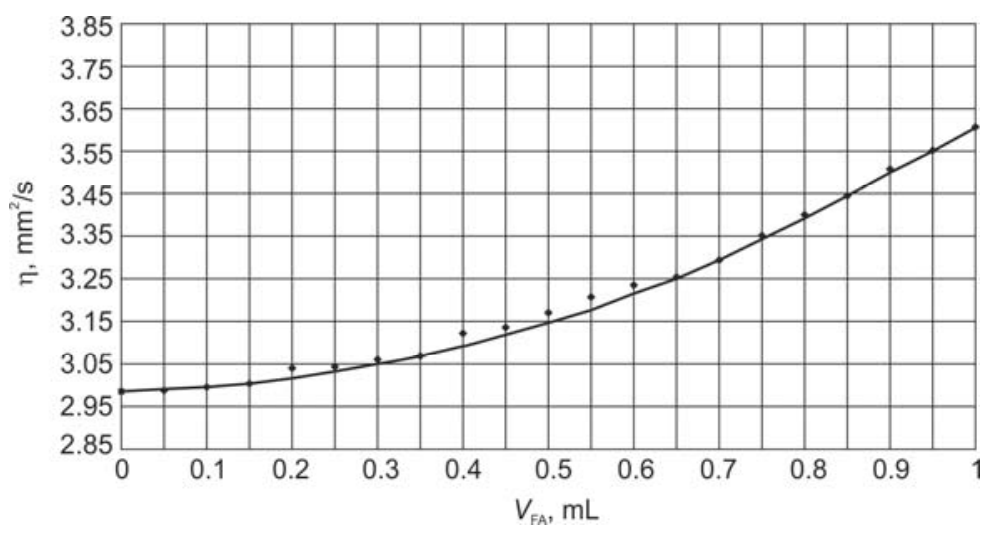

Fig. 1. The value of $\eta$ of AFES versus $V$ of added FA "Snizok-1"

Curve rate on a graphic (Fig. 1) reveals that fluidity of AFESs solutions after addition of FA is being augmented. Undoubtedly, it provides the penetration of greater quantities of liquid into combustion zone upon same duration of time. As a result of it concentration of fire extinguishing substance in a flame is being increased.
Table 2

Measurement results of kinematic viscosity $(\eta)$ for samples of AFESs with FA

\begin{tabular}{|l|c|}
\hline Sample* & $\eta, \mathrm{mm}^{2} \cdot \mathrm{s}^{-1}$ \\
\hline Distilled water & $1,2023(35)$ \\
\hline FA "Snizok-1" & $7,0679(35)$ \\
\hline $40 \%(\mathrm{~W} / \mathrm{W})$ of $\mathrm{CuCl}_{2}$ & $2,9875(35)$ \\
\hline $0.1 \%(\mathrm{~V} / \mathrm{V})$ of $\mathrm{FA}$ in $40 \%(\mathrm{~W} / \mathrm{W})$ of $\mathrm{CuCl}_{2}$ & $2,9875(35)$ \\
\hline $0.2 \%(\mathrm{~V} / \mathrm{V})$ of FA in $40 \%(\mathrm{~W} / \mathrm{W})$ of $\mathrm{CuCl}_{2}$ & $2,9966(35)$ \\
\hline $0.3 \%(\mathrm{~V} / \mathrm{V})$ of FA in $40 \%(\mathrm{~W} / \mathrm{W})$ of $\mathrm{CuCl}_{2}$ & $3,0057(35)$ \\
\hline $0.4 \%(\mathrm{~V} / \mathrm{V})$ of FA in $40 \%(\mathrm{~W} / \mathrm{W})$ of $\mathrm{CuCl}_{2}$ & $3,0421(35)$ \\
\hline $0.5 \%(\mathrm{~V} / \mathrm{V})$ of $\mathrm{FA}$ in $40 \%(\mathrm{~W} / \mathrm{W})$ of $\mathrm{CuCl}_{2}$ & $3,0467(35)$ \\
\hline $0.6 \%(\mathrm{~V} / \mathrm{V})$ of FA in $40 \%(\mathrm{~W} / \mathrm{W})$ of $\mathrm{CuCl}_{2}$ & $3,0603(35)$ \\
\hline $0.7 \%(\mathrm{~V} / \mathrm{V})$ of $\mathrm{FA}$ in $40 \%(\mathrm{~W} / \mathrm{W})$ of $\mathrm{CuCl}_{2}$ & $3,0694(35)$ \\
\hline $0.8 \%(\mathrm{~V} / \mathrm{V})$ of FA in $40 \%(\mathrm{~W} / \mathrm{W})$ of $\mathrm{CuCl}_{2}$ & $3,1241(35)$ \\
\hline $0.9 \%(\mathrm{~V} / \mathrm{V})$ of FA in $40 \%(\mathrm{~W} / \mathrm{W})$ of $\mathrm{CuCl}_{2}$ & $3,1378(35)$ \\
\hline $1.0 \%(\mathrm{~V} / \mathrm{V})$ of FA in $40 \%(\mathrm{~W} / \mathrm{W})$ of $\mathrm{CuCl}_{2}$ & $3,1696(35)$ \\
\hline $1.1 \%(\mathrm{~V} / \mathrm{V})$ of FA in $40 \%(\mathrm{~W} / \mathrm{W})$ of $\mathrm{CuCl}_{2}$ & $3,2114(35)$ \\
\hline $1.2 \%(\mathrm{~V} / \mathrm{V})$ of FA in $40 \%(\mathrm{~W} / \mathrm{W})$ of $\mathrm{CuCl}_{2}$ & $3,2367(35)$ \\
\hline $1.3 \%(\mathrm{~V} / \mathrm{V})$ of FA in $40 \%(\mathrm{~W} / \mathrm{W})$ of $\mathrm{CuCl}_{2}$ & $3,2544(35)$ \\
\hline $1.4 \%(\mathrm{~V} / \mathrm{V})$ of FA in $40 \%(\mathrm{~W} / \mathrm{W})$ of $\mathrm{CuCl}_{2}$ & $3,2941(35)$ \\
\hline $1.5 \%(\mathrm{~V} / \mathrm{V})$ of FA in $40 \%(\mathrm{~W} / \mathrm{W})$ of $\mathrm{CuCl}_{2}$ & $3,3543(35)$ \\
\hline $1.6 \%(\mathrm{~V} / \mathrm{V})$ of FA in $40 \%(\mathrm{~W} / \mathrm{W})$ of $\mathrm{CuCl}_{2}$ & $3,4022(35)$ \\
\hline $1.7 \%(\mathrm{~V} / \mathrm{V})$ of FA in $40 \%(\mathrm{~W} / \mathrm{W})$ of $\mathrm{CuCl}_{2}$ & $3,4454(35)$ \\
\hline $1.8 \%(\mathrm{~V} / \mathrm{V})$ of FA in $40 \%(\mathrm{~W} / \mathrm{W})$ of $\mathrm{CuCl}_{2}$ & $3,5141(35)$ \\
\hline $1.9 \%(\mathrm{~V} / \mathrm{V})$ of FA in $40 \%(\mathrm{~W} / \mathrm{W})$ of $\mathrm{CuCl}_{2}$ & $3,5511(35)$ \\
\hline $2.0 \%(\mathrm{~V} / \mathrm{V})$ of FA in $40 \%(\mathrm{~W} / \mathrm{W})$ of $\mathrm{CuCl}_{2}$ & $3,5886(35)$ \\
\hline
\end{tabular}

Note: ${ }^{*}-\%(W / W)$ is weight/weight percent and \% $(V / V)$ is volume/volume percent.

\section{3. The specific density and surface tension} for samples of AFESs with FA

The determination of specific density for AFESs has been carried out by bottle method. The gist of this method lies in weighing on electronic balance of the precisely filled pycnometer $(50 \mathrm{~mL})$ with investigated solution at $20{ }^{\circ} \mathrm{C}$. The results of specific density measurement are given in Table 3 .

The surface tension $(\sigma)$ for AFESs has been determined by method of drops account using stalagmometer. This installation is equipped by the dropping tube on $1 \mathrm{~mL}$ with scale interval of $0.01 \mathrm{~mL}$ and burette on $10 \mathrm{~mL}$. The based on the account of drops that are generated by distilled water $\left(n_{0}\right)$ or investigated solution (n) flowing out of pipet were calculated the values of $\sigma$. All measurements for each sample were performed in triplicates and their values were averaged. Thus, the value of $\sigma$ can be represented as

$$
\sigma=\sigma_{0} \frac{\rho n_{0}}{\rho_{0} n},
$$

where $\sigma_{0}$ is surface tension for distilled water whose value amounts $72.75 \mathrm{mN} \cdot \mathrm{m}^{-1}$ at $20^{\circ} \mathrm{C}, \rho_{0}$ and $\rho$ are specific density of distilled water and investigated solution, respectively (Table 3 ). The graphical relationship between values of $\sigma$ and volume $(V, \mathrm{~mL})$ of added FA "Snizok- 1 " is displayed in Fig. 2. 
Table 3

Measurement results of specific density $(\rho)$ and surface tension $(\sigma)$ for samples of AFESs with FA

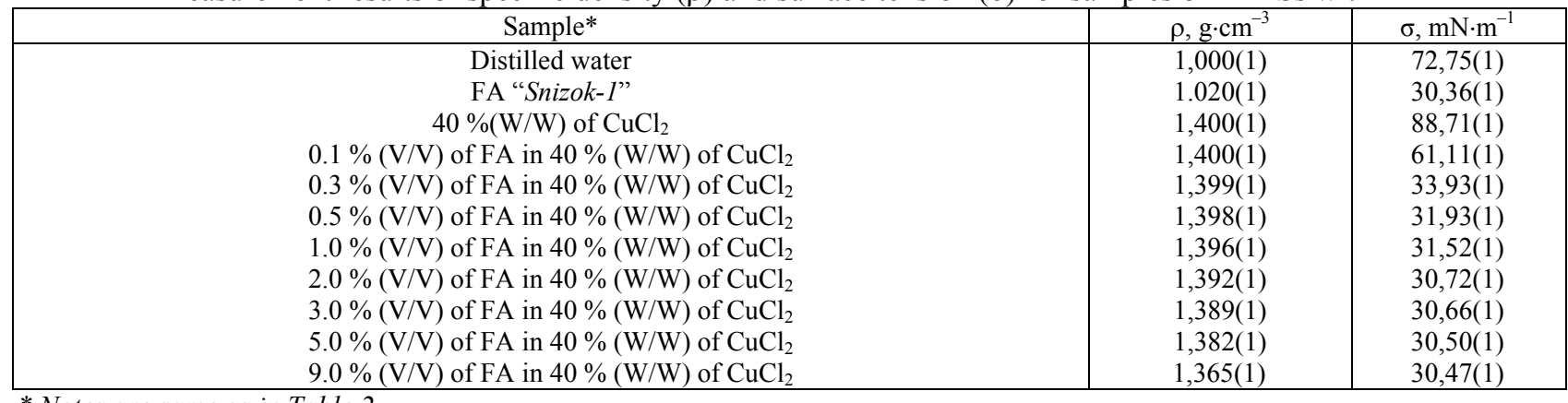

* Notes are same as in Table 2

So, the addition of foaming agent of special purpose "Snizok-1" for fire extinguishing in indicated quantity provides for decreasing of surface tension of initial $40 \%$ aqueous solution of copper(II) chloride from $88.71(1)$ to $30.47(1) \mathrm{mN} \cdot \mathrm{m}^{-1}$ in case of FA content at $9 \%$ $(\mathrm{V} / \mathrm{V})$. In turn the lowering of surface tension increases dispersity of AFES aerosol at the injecting of it into a flame. Hence, it increases the area of surface that contacts with radicals of a flame and particles of fire extinguishing substance. Nevertheless, for effective decrease of a surface tension it is enough to add foaming agent "Snizok-1" slightly more than $0.3 \%(\mathrm{~V} / \mathrm{V})$ whereas the subsequent adding of FA practically no leads to lowering of value of $\sigma$ (Fig. 2).

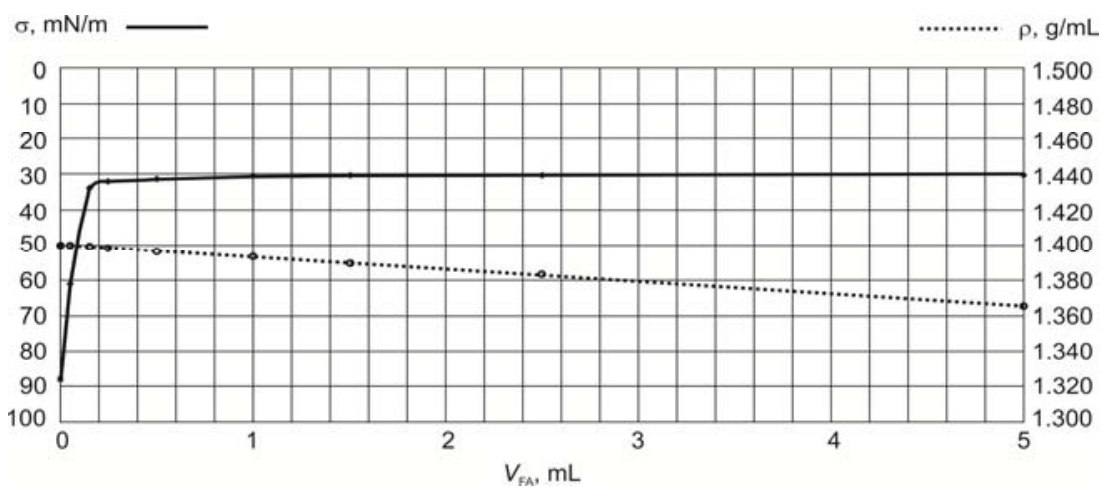

Fig. 2. The value of $\sigma$ and $\rho$ of AFES versus $V$ of added FA "Snizok-1"

\section{Approbation of the research results}

The ascertained quality metrics of AFESs allow choosing optimal compositions of solutions which prove much-needed for the effective suppressing of a flame in systems being used technologies of spraying. So, results of fire extinguishing tests by means of AFES confirm that comparatively with water the efficiency coefficient of flame suppressing (designated as $K_{1}$ ) by aerosol of $40 \%$ aqueous solution of $\mathrm{CuCl}_{2}$ containing about $0.2 \%$ of FA "Snizok-1" increases in 18.2 times whereas the value $K_{1}$ for same solution without FA equals to 16.3 .

\section{Conclusion}

Thus, the application of diverse methods of the physical and chemical analysis has given a chance to establish the main quality metrics such as appearance, kinematic viscosity and surface tension, freezing temperature, acidity and density of $40 \%$ aqueous solution of copper (II) chloride with added foaming agent of special purpose "Snizok-1". These data is needed for subsequent using these solutions as AFES for technology of spraying under firefighting.

\section{References}

1. Mykhalitchko, B. M. The water-based fireextinguishing agent «WGHM-II» [Text] / B. M. Mykhalitchko, V. V. Kovalyshyn, N. M. Godovanets // Patent UA No 102757 C2. - 2013. - № 15 .
2. Godovanets, N. M. Fire testing of aqueous fireextinguishing agent on base of copper(II) chloride [Text] / N. M. Godovanets, B. M. Mykhalitchko, V. L. Petrovskii, O. N. Scherbina // Fire safety problems. - 2013. - Issue 33. P. 38-44.

3. Mykhalitchko, B. M. Experimental determination technique of extinguishing efficiency of aqueous solutions of mineral salts [Text] / B. M. Mykhalitchko, O. N. Scherbina, N. M. Godovanets, V. L. Petrovskii // Fire safety. - 2013. Vol. 22. - P. 183-187.

4. Kopylov, N. Study of mechanism of a quenching of the model centers of a fire by the finely sprayed water [Text] / N. Kopylov, A. Chibisov, A. Dushkin, E. Kudriavcev // Fire Safety. -2008. - Vol 4. - P. 45-58.

5. Alehanov, Yu. Interaction of dispergated water with flame [Text] / Yu. Alehanov, M. Bliznecov, Yu. Vlasov, V. Dudin, A. Levushov, A. Logvinov, S. Lomtev, E. Meshkov // Letters J. Techn. Physics. - 2003. - Vol. 29, Issue 6. - P. 1-6.

6. Kovregin, V. Increase of efficiency extinguishing compositions on the water basis at the expense of various reagents additives [Text] / V. Kovregin, V. Kalugin, M. Kustov, O. Sidorenko // Bull. LSULS. - 2010. - Vol 4, Issue 1. P. 136-142.

7. Turchin, A. Theoretical and experimental aspects of application technologies for fine spraying of water-based fire extinguishing substances [Text] / A. Turchin, A. Antonov // Sci. Bull. UkrSRIFS. - 2008. - Vol. 17, Issue 1. - P. 138-145.

8. Turchin, A. The investigation for determination of quality coefficient of some water-based fire-extinguishing agents [Text] / A. Turchin, V. Borovikov, A. Antonov, N. Koziar // Sci. Bull. UkrSRIFS. - 2008. -Vol. 18, Issue 2. - P. 110-115. 
9. Antonov, A. The water-based fire-extinguishing agent for fire extinguishing of " $A$ " and "B" types by sprayed jets in compliance with all-Union State Standard 27331-87 by using of -30 to $+50^{\circ} \mathrm{C}$ [Text] / A. Antonov, V. Kovalyshyn, A. Turchin, N. Koziar // Patent UA No 52969 U. 2008. Bull. № 18 .

10. Antonov, A. V. The water-based fire-extinguishing agent for fire-extinguishing of " $\mathrm{A}$ " and "B" types by sprayed jets in compliance with all-Union State Standard 27331-87 [Text] / A. V. Antonov, V. V. Kovalyshyn, A. I. Turchin, M. N. Vaisman, N. M. Koziar // Patent UA No 96797 C2. 2011. Bull. № 23.

11. Korobeinichev, O. P. Fire suppression by aqueous solutions salts aerosols [Text] / O. P. Korobeinichev, A. G. Shmakov, A. A. Chernov, T. A. Bol'shova, V. M. Shvartsberg, K. P. Kutsenogii, V. I. Makarov // Comb. Expl. Shock Waves. - 2010. - Vol. 46, Issue 1. - P. 20-25.

\section{References}

1. Mykhalitchko, B. M., Kovalyshyn, V. V., Godovanets, N. M. (2013). The water-based fire-extinguishing agent «WGHM-II». Patent UA No 102757 C2, Bulletin, 15.

2. Godovanets, N. M., Mykhalitchko, B. M., Petrovskii, V. L., Scherbina, O. N. (2013). Fire testing of aqueous fireextinguishing agent on base of copper(II) chloride. Fire safety problems, 33, 38-44.

3. Mykhalitchko, B. M., Scherbina, O. N., Godovanets, N. M., Petrovskii, V. L. (2013). Experimental determination technique of extinguishing efficiency of aqueous solutions of mineral salts. Fire safety, 22, 183-187.

4. Kopylov, N., Chibisov, A., Dushkin, A., Kudriavcev, E. (2008). Study of mechanism of a quenching of the model centers of a fire by the finely sprayed water. Fire Safety, 4, 45-58.

5. Alehanov, Yu., Bliznecov, M., Vlasov, Yu., Dudin, V., Levushov, A., Logvinov, A., Lomtev, S., Meshkov, E. (2003) Interaction of dispergated water with flame. Letters Jorn. Techn. Physics, 29 (6), 1-6.

6. Kovregin, V. V, Kalugin, V. D., Kustov, M. V. Sidorenko, O. V. (2010). Increase of efficiency extinguishing structures on the water basis at the expense of various reagents additives. Bull. LSULS, 4, Part 1, 136-142.

7. Turchin, A., Antonov, A. (2008). Theoretical and experimental aspects of application technologies for fine spraying of water-based fire extinguishing substances. Science Bull. UkrSRIFS, 17 (1), 138-145.

8. Turchin, A. I., Borovikov, V. O., Antonov, A. V., Koziar, N. M. (2008). The investigation for determination of quality coefficient of some water-based fire-extinguishing agents Science Bull. UkrSRIFS, 18 (2), 110-115.

9. Antonov, A. V., Kovalyshyn, V. V., Turchin, A. I., Koziar, N. M. (2009). The water-based fire-extinguishing agent for fire extinguishing of "A" and "B" types by sprayed jets in compliance with all-Union State Standard 27331-87 by using of -30 to $+50{ }^{\circ} \mathrm{C}$. Patent UA No 52969 U, Bulletin, 18 .

10. Antonov, A. V., Kovalyshyn, V. V., Turchin, A. I., Vaisman, M. N., Koziar, N. M. (2011). The water-based fireextinguishing agent for fire-extinguishing of "A" and "B" types by sprayed jets in compliance with all-Union State Standard 27331-87. Patent UA No 96797 C2, Bulletin, 23.

11. Korobeinichev, O. P., Shmakov, A. G., Chernov, A. A., Bol'shova, T. A., Shvartsberg, V. M., Kutsenogii, K. P., Makarov, V. I. (2010). Fire suppression by aqueous solutions salts aerosols. Comb. Expl. Shock Waves, 46 (1), 16-20.

Дата находження рукопису 22.06.2015

Mykhalichko Borys, Doctor of Science (chemistry), Professor, Department of burning processes and General Chemistry. L'viv state university of life safety, Kleparivs'ka Str., 35, L'viv, Ukraine, 79007

E-mail: mykhalitchko@email.ua

Scherbina Olga, Philosophy doctor (pharmaceutics), Docent, Department of burning processes and General Chemistry, L'viv state university of life safety, Kleparivs'ka Str., 35, L'viv, Ukraine, 79007

Mykhalichko Oleg, Philosophy doctor (chemistry), Chemist Analyst, Chemical analysis laboratory. "FUCHS MASTYLA UKRAINA” LLC, Shevchenka Str., 327-A, L’viv, Ukraine, 79069

E-mail: o.mykhalichko@fuchs-oil.com.ua

Petrovskii Vitalii, Without scientific degree, Senior researcher, Testing laboratory of fire safety, L'viv state university of life safety, Kleparivs'ka Str., 35, L’viv, Ukraine, 79007

\section{УДК 664.292 \\ DOI: $10.15587 / 2313-8416.2015 .45905$}

\section{ТЕРМОГРАВІМЕТРИЧНИЙ АНАЛІЗ ПЕКТИНОВИХ ГЕЛІВ}

\section{(C) І. О. Крапивницька, П. В. Гурський, Ф. В. Перцевий}

Термогравіметричним методом за постійної швидкості нагрівання досліджено втрати маси та швидкість перетворень, щзо відбуваються в гелях ичитрусового та яблучного пектину різного ступеня етерифікації та вплив циттрату натрію на втрати маси гелю пектину низькоетерифікованого. Встановлено залежність ступеня зміни маси від температури гелів циитрусового та яблучного пектину з високого та низького ступеня етерифікаиї

Ключові слова: ендоефекти, термостабільність, ендотермічний процес, дегідратація, термоаналіз, форми зв'язку вологи

A weight loss and speed change occurring in gels of citrus and apple pectin of different degree of esterification and the effect of sodium citrate on the mass loss of low pectin gel are studied by thermographic technique constant heating rate. The dependence of the degree of weight change on temperature of gel of citrus and apple pectin with high and low degree of esterification is determined

Keywords: endo-effects, thermal stability, endothermic process, dehydration, thermal analysis, forms of moisture binding 